\title{
Key drivers of customer value in business-to-business security guard services
}

\author{
M. Jähi \\ VTT Technical Research Centre of Finland, Finland
}

\begin{abstract}
The private security industry has witnessed dramatic growth during the past few decades, but despite the remarkable growth, there is a lack of empirical studies focusing on the customer value of private security services. Much of the existing literature on private security focuses on the causes of its growth and on good governance practices, while very little attention has been paid to the actual process of value creation. The aim of this study is to deepen the understanding of private security services by exploring value creation of security guarding from the customer's perspective, i.e., the actual benefits and sacrifices as well as the customer-relationship aspects perceived by the customer. The study is based on open-ended interviews $(\mathrm{n}=15)$ with business-to-business customers of three security service providers. The study follows the paradigm of social constructionism and an active interview approach. The key drivers of customer value are presented as a result of a qualitative thematic analysis. The findings of the study reveal that customer value is centred on two main themes: guarding services as a guarantee for security and guarding services as professional business-to-business services. In total, nine value drivers that influence customer value are identified. In the first theme, they are reactivity, reliability, presence and personal characteristics. In the second theme, they are balance between duties, communication, relationship management practices, and time and effort. As a conclusion, the study argues that security guard services should not only be evaluated in relation to crime prevention and security provision but take into consideration all the security guards' duties, including, e.g., customer service and housekeeping. A new term security-service dilemma is also introduced to describe the difficulties of combining security-related duties with non-security duties in one service concept.
\end{abstract}

Keywords: customer value, private security, security guarding, services. 


\section{Introduction}

Private security services have witnessed dramatic growth during the past few decades (De Waard [1]; Van Steden and Sarre [2]). At the same time, the duties of security guards have expanded and grown more complex [1]. Even though there is some controversy over the exact size of the industry [2], it can be argued that private security services have become an integral part of almost every business and public sector organisation in Europe and elsewhere. Despite this remarkable growth, there is limited research into private security services. Much of the present literature on private security focuses on good governance practices or negative societal consequences (e.g., Zedner [3]; Prenzler and Sarre [4]; Van Steden and Sarre [5]). The increase in supply and demand in the industry and the causes of the growth have also been reviewed in detail $[1,2]$. There is a lack of studies focusing on private security services, however, from the managerial perspective and the customer's perspective, even though the need for such studies was recognised by Johnson [6] two decades ago.

This study aims to bridge the existing managerial research gap by exploring private security guard services from the perspective of customer value. The goal is to uncover the way customers of security guard services perceive the benefits of these services. Why do they buy these services in the first place? What are the practical benefits? How is the performance of the service provider evaluated?

The emphasis on customer value is on the perceptions of the customer while addressing a comprehensive evaluation of the customer-perceived benefits and sacrifices by a certain product or service (Zeithaml [7]). As a concept, customer value has been widely used in marketing for at least two decades and there is a considerable amount of theoretical and empirical literature focusing on the customer value in business markets (Lindgreen and Wynstra [8]). Very little attention has been paid to customer value in the context of private security guard services however.

The focus of this paper is on manned guarding services, which represent the largest segment of the private security industry [5]. Technology-based services (alarm systems, CCTV, mechanical security equipment, etc.) are only examined insofar as it is necessary to understand the work of the security guards. In-house security services and personal security services are excluded from the study because they cannot be regarded as business-to-business services. The paper is structured as follows. First, the security guard service and customer value literature are reviewed to form a basis for the analysis and to position the study within private security and marketing literature. Second, the research methodology is introduced. Third, the empirical findings are presented. Finally, the implications and limitations of the study are discussed.

\section{Background}

\subsection{Security guard services}

Security is not a singular concept and, as a definition, it is dependent on an applied context (Brooks [9]). For example, security can be regarded as an 
objective or subjective condition (Zedner [10]). In the context of security guarding, the concept of security is related to the functions of the security guards. Sarre and Prenzler [11] define security guards as persons employed or sponsored by a commercial enterprise on a contract or in-house basis, using public or private funds, to engage in tasks in which the principal component is a security or regulatory function. Traditionally semi-public places, e.g., shopping centres and industrial sites, have been regarded natural spheres of influence for security guards. Guarding personnel are now also present in the wider public domains of towns and cities as van Steden and Sarre [5] have noticed.

A traditional method to measure the effectiveness of security guard services is to consider its consequences for crime prevention. For example, based on a literature review by Welsh et al. [12], there is some evidence that the use of security guards can be an effective method to prevent crimes in public spaces when implemented in car parks and targeted at vehicle crimes. Crime prevention is just one of several duties performed by the security guards in their daily work however. In a shopping centre environment, for instance, security guards are responsible for housekeeping, customer care, preventing crime and anti-social behaviour, rule enforcement and the use of sanctions, responding to emergencies and offences in progress, and gathering and sharing information (Wakefield [13]). To understand properly the work and tasks performed by the security guards, all the above-mentioned duties, including crime prevention, have to be taken into consideration. The 'principal component' of the duties of security guards can be a security or regulatory function, as stated by the definition by Sarre and Prenzler [11], but it does not suggest that these other non-securityrelated functions are of no value to the customer.

There are a few examples of well-documented cases and field studies on the work of security guards. For instance, Wakefield [13] and Button [14] have described in detail the routines, challenges and expectations related to security guarding in a shopping centre environment. These studies give valuable insights into the practice of the occupation. In spite of the definite advantages of the approach used in these studies, however, they only represent one type of security guarding and do not put systematic emphasis on the views of the customers of these services. This lack of customer perspective has been a deficiency in private security research for some time, while the main research focus has been more on criminology, law studies and sociology (e.g., [3-6], Manzo [15]) than on private security services as a business. In this respect, the customer value is also a promising concept when studying private security services while addressing a comprehensive evaluation of benefits and sacrifices from the perspective of the customer.

\subsection{Customer value}

The concept of value as such is multifaceted and has different meanings in the field of economics, philosophy and business (Woodall [16]). In marketing literature, customer value is traditionally understood as the customer's overall assessment of the utility of a product based on the perceptions of what is received and what is given [7]. In the context of business-to-business markets, 
Ulaga and Chacour [17] have defined customer value as the trade-off between the multiple benefits and sacrifices of a supplier's offering, as perceived by key decision-makers in the customer's organisation, and taking into consideration the available alternative suppliers' offerings in a specific-use situation. In practice, value can be added to the customer in several ways, and as Ravald and Grönroos [18] have noticed, value can be provided not only by offering more benefits but also by reducing the customer's overall sacrifices.

Different benefits and sacrifices can be categorised in many ways. One simple method is to classify benefits as attributes and outcomes, and sacrifices as monetary and non-monetary [16]. Attributes consist of product and service quality as well as core product and added service features. Outcomes can be categorised as strategic, personal, social, practical and financial benefits. Price, acquisition, distribution and learning costs are examples of monetary costs; and relationship costs, time and effort are examples of non-monetary costs. Some authors have argued that more emphasis should be put on the outcome side of the benefits and sacrifices taxonomy, i.e., the value-in-use instead of the more traditional value-in-exchange approach. For example, Woodruff [19] has developed a customer value hierarchy model to emphasise the role of achieving the customer's goals in value creation in use situations. Moreover, the importance of the customer's perspective in value creation has been highlighted by Grönroos [20], who has argued that the customer is the principal value-creator in use situations and that the producer can only be a value co-creator with its customers.

In addition to the research stream described above of the value of goods and services, the customer value can be examined by focusing on the value of the buyer-seller relationship [8]. This relationship value approach considers customer value from the viewpoint of relationship marketing (Payne and Holt [21]). According to Grönroos [22], relationship marketing can be regarded as a perspective on value creation, which draws attention to cooperation, trust and commitment between buyer and seller.

The focus of this study is not on the various definitions and interpretations of customer value as such. As a concept, customer value has been thoroughly studied during the past two decades, and it is only possible to show a fraction of this research in this paper. This study uses customer value as a perspective to explore the security guard services from the viewpoint of the customer. In this regard, the customer value is understood as comprising both value-in-exchange and value-in-use approaches as well as relationship value aspects. In the analysis, however, the actual construction of customer value in security guard services is left to the respondents.

\section{Methodology}

\subsection{Research philosophy}

The choice of method embodies an array of assumptions regarding the nature of the knowledge and methods through which that knowledge can be obtained 
(Morgan and Smircich [23]). This study is based on the philosophical tradition of social constructionism. From the viewpoint of social constructionism, the goal of the research is to show how different constructions and meanings are placed on the experiences of people rather than on gathering facts and measuring some occurring patterns (Easterby-Smith and Thorpe [24]). The focus of this study is on the experiences of customers of private security service providers. As discussed in the literature review, customer value is based on the actual benefits and sacrifices perceived by the customer. These experiences are subjective by nature and are dependent on the situational factors. From the viewpoint of social constructionism, they can therefore be regarded as social constructions.

\subsection{Data collection}

The informants ( $\mathrm{n}=15 ; 5$ women, 10 men) were customers of three security service providers and were chosen to represent the whole range of customers of security guard service providers including light industry, commerce, the public sector and offices. The interviewees represented ten different organisations, and they were responsible in their organisations for buying and developing security guard services and keeping in contact with the security guard service providers. The interviewees had titles such as managing director, finance director, head of technical services, property manager, security manager, etc. In short, the interviewees were the decision-makers or so-called gate-keepers and had major influence over the decision-making in their organisations.

The data were collected using active and open-ended interviews. Open-ended interviews are usually preferred because they allow the interviewees to use their own ways of defining the world, do not assume that a fixed sequence of questions is suitable for all respondents and allow the interviewees to raise questions that are not pre-scheduled (Denzin [25]). A basic stance of an active interview was adopted throughout the data collection phase. In the active approach to interviewing, the subject behind the respondent is regarded not only as holding facts and details of experiences but also constructively adds to, takes away from and converts the fact and details under investigation (Holstein and Gubrium [26]).

The interview guide consisted of two parts. In the first part, the interviewees were asked to describe one or more examples (narratives) of actual guarding situations in which there have been exceptionally good and bad results on behalf of the security guards. A critical incident technique (Flanagan [27]) was used as a guiding tool for these discussions. The respondents were asked to describe in as much detail as possible what had actually happened and what had made $\mathrm{him} /$ her consider the incident as critical [22]. In the second part of the interview guide, more specific topics were discussed with the respondents. The basic reasons for acquiring the security guard services were discussed, followed by the benefits and sacrifices of security guarding and the practice of the buyer-seller relationship. The interviews lasted from 60 to 90 minutes. 


\subsection{Analysis and interpretation}

All the interviews were digitally recorded and transcribed, and the transcribed data were then coded using Atlas.ti software. Field notes and memos were produced during and immediately after the interviews, and they were also used as secondary data during the analysis. The data analysis started by listening to the recordings and reading the transcripts, and continued with coding and recoding. In the process, several code families were created with different subcode categories. After the first interviews, the preliminary results were used to provide guidance for the rest of the interviews.

After the coding, a thematic analysis was used to categorise the data into themes that presented the data as a coherent set of topics, questions and conversations. In the process, two major themes emerged from the data: guarding services as a guarantee for security and guarding services as professional business-to-business services. The analysis was then continued by defining the value drivers separately for the themes.

\section{Results}

\subsection{Guarding services as a guarantee of security}

The respondents of the study were unanimous and explicit about the basic motives of buying security services. In all the cases, the starting point for the purchasing decision was founded on security threats. In a typical case, the buying of security services was a way to handle emergencies as well as to prevent anticipated crimes and material losses, as illustrated in the following quote:

Respondent 3 (R3): In my opinion, the most important things are that they [security guards] come quickly when needed and that they are present and in sight. It is the key to everything that they are present.

According to the respondents of this study, reliability and the ability to react quickly to various emergencies were basic requirements for the security guards. High reactivity and high reliability were expected from the service provider in all conditions. When there was an emergency or a situation in which the security guards were needed, the respondents' main concern was to be able to alarm the security guards as quickly as possible, make sure that somebody at the service provider's call centre answered the phone and that security guards would come as fast as agreed in the contract. This is in line with Wakefield [13] who states that the preventive role has been regarded as the most important role of security guards in semi-public places such as shopping centres or cultural centres. This study also indicates that abilities to prevent crimes and disorder were as important as reacting to various emergencies. In a number of cases, it was the most important reason behind the buying decision. 
The value of the presence of security guards was also strongly linked to the prevention and minimisation of damages caused by fire, water leaks and other possible material accidents as exemplified in the next quote:

R10: For example, in the laboratory the [weekend] route of the patrol was changed so that it would go through the laboratory where all these devices, which are connected to the water system, are. So, if there is water damage, then it would be noticed before Monday morning.

An ability to react to different emergencies can be regarded as representing an objective side of security. Realised emergencies and concrete actions of security guards can, for example, be reported, quantified and measured. In addition to the objective and measurable features described above, security can also be understood as a subjective condition [10]. This subjective side of security was present in the discussions with the respondents throughout the data, and it was explicitly expressed by one shopping centre operator:

R1: The atmosphere has to be pleasant, feel relaxed, like coming home. (...) Of course there are other things that have an effect on it, but these security services, and that we have these security guards here who do their work very well, make people feel that it is nice to come here. (...) It is this feeling. That's what we're buying.

The respondents also expressed a view that the personal skills and attitudes of the security guards have a huge influence on assessing the service quality. This is well illustrated in the following statement of a respondent representing accommodation business:

R7: We can't bring 'Rambo' here because we're working with ordinary people, and this is no jail; this is a hotel. I mean, things have to go quite smoothly, and it paints a good picture for our customers too if we have a security guard who knows what to do and who can be friendly.

Social skills were not the only personal skills required from the individual security guards. In fact, a different set of skills were needed depending on the customer's characteristics and type of industry. In addition to social skills, customers were looking for the ability to use force, other security skills, varying technical competence and language skills. From the value creation point of view, the most important factor, according to the respondents, was not the skills of a particular security guard per se but rather choosing the most suitable personalities for the right duties.

In summary, guarding services as a guarantee for security can be described using four drivers for customer value: reactivity, reliability, presence and personal characteristics.

\subsection{Guarding services as professional business-to-business services}

The Management of security threats, as described in the previous chapter, was a basic motive for buying security services. Another theme, i.e., guarding services 
as professional business-to-business services, was also present throughout the data. In the taxonomy of services, professional services are defined as services delivered to organisations by service providers (business-to-business services) (Barry and Terry [28]). In this study, the term professional services is used to describe all the discussions with the respondents who presented security guarding mainly as a form of business-to-business service and as categorised into the same type of services as cleaning contractors, janitorial services and catering. The main focus of these discussions was not on security but on the service operations performed by the security guards on the whole and on the practice of customer-relationship management.

The discussions with the respondents revealed that the security guards performed a wide range of duties, of which only some can be regarded as security duties. According to the respondents, a central question on service operations was how to combine a set of different duties into one meaningful service concept? The work of the security guards included a variety of duties for every buyer-seller relationship explored in this study. The balance between security-related and other duties, namely customer-service-related duties, varied between respondents. This thematic was present to some extent in each interview however. For some customers, the non-security-related duties were as important as crime prevention and responding to emergencies:

R4: From our point of view, (...) if they don't arrange our seminar rooms and change the light bulbs and other things like that... it's these things that are as important to us as security.

The respondents of the study reported that what mattered most was the right balance between all the kinds of duties and tasks performed by the security guards. Security guards were expected to do their basic work as well as some extra services when needed. What emerged from the discussions was the central problem of combining security with other non-security tasks. This problem is called a security-service dilemma in this paper, and it is described well by one of the respondents:

R7: In security service like that, it can work very well 99 per cent of the time; then there is this one case when the security guard is somewhere fixing a door instead of taking care of this guy who is acting violently.

Based on the views of the respondents, there is no easy solution to this dilemma. If the service provider can present a solution by using a combination of resources (labour, technology, time, etc.) and expertise, however, and that provides reasonably good results for the customer, it forms a good starting point for a buyer-seller relationship. An example could be a team of security personnel that can allocate its work as a self-organising unit taking care that there is always enough manpower to handle an emergency or surveillance. In practice, this could prove very difficult to realise and, in many cases, no extra resources are available.

One problem of defining the service offering was often poor communication and misunderstandings of the service contents. If the representatives of the 
customer and/or security guards were unaware of what exactly was required of the security guards, confusion and misunderstandings resulted, eventually leading to disappointment and a decrease in customer-perceived service quality:

R2: Sometimes (...) we have asked a guard, I don't mean cleaning in general, but like pick up some trash there; some guys do it, but for some others it seems to be very hard to pick up a paper bag and put it into a dustbin.

Button [14] has noticed that in many cases, security guards have to serve more than one master at the same time (i.e., customers, supervisors, owners, etc.), which can produce unnecessary stress and make the daily work complicated. The results of this study are in line with this finding, and it is argued that security service providers should pay attention to this problem in order to create good prerequisites for value creation.

In light of customer value literature, customer-relationship practices are a particularly important aspect of value creation in services [22]. According to the respondents of this study, security guard services are no exception. The respondents put great emphasis on, for example, the way service providers maintain contact with the customer organisation, the way the service content is developed and how proactively the service provider operates. Close and personal relationships between key account managers and other contact persons on both sides was a sign of good customer-relationship management and had a positive influence on customer value. One respondent gave an example of a wellfunctioning relationship between the security service provider and the customer:

R6: They make us feel like we're number one, and in my opinion that is an enormous achievement. (...) I can call the key account manager whenever I want and he always has time for me.

Some authors have argued that security shares some characteristics with public good, and it should not be sold as a private commodity while it has great societal consequences (i.e., externalities) [3]. This study did not take this publicprivate debate actively into consideration while concentrating on the views of the customers. Discussions with the respondents, however, revealed clearly that the customers of the security guard services did not see conceivable societal consequences of private security services as a part of their value creation process. For the respondents of this study, security and security guard services were private professional services (i.e., private commodities), and they were classified in the same category as cleaning and other maintenance services. The only form of societal consequences that was present in the data was image losses. Some respondents were afraid of negative publicity if the security guards behaved inappropriately, for example, using unnecessary violence:

R13: Some of our big customers, for example, I mean the security guard provider can really blow it (...) if they use force on the wrong person who happens to be here inside our premises. 
Even if this sort of publicity risk was real for some of the respondents, the main concern was one of private risks and losses to the respondent's company, not to society at large.

The price of security guard services was a major component of customer value throughout the data. When respondents were asked to describe the criteria for selecting a security service provider, the price emerged as a principal component. Despite being a principal component, the respondents always presented price in relation to some qualitative criteria. This was well illustrated by one respondent:

R11: And the price is like this, if we are very satisfied with our partner, then the price is what it is. (...) What matters is how well they do their duty. If it is done well, then we have a good situation, and we let it [price] be like that.

Moreover, the respondents also evaluated the price of the security guard services in relation to the time and effort required if the service provider were changed. Respondents expressed a view that changing the service provider required a great amount of time and energy, especially in the form of training and education of the new service provider and security guards. As the required time and energy were regarded as a considerable sacrifice, respondents were not willing to change their service provider unless the cost reduction was significant:

R9: You don't want to do it too often (...) we like to do a longer deal (...) while this is that kind of service that requires quite a lot of development, learning and things like that. If you change it [service provider] every year, at worst, they have just learnt all the premises.

In summary, security guard services, as professional services, can be described using four drivers for customer value: balance between duties, communication, customer-relationship practices, and price, time and effort.

\section{Conclusions}

As a conclusion, the study argues that security guard services should not only be examined in relation to security provision, while the customers of these services consider security guarding more in terms of professional business services than as a special industry of its own (e.g., security industry or private policing). The management of security is a very important component of the value-creation process, but it is not the only thing that has particular value for customers. The findings of the study implicate that much of the value creation of security guarding is linked to customer-relationship management practices, communication, customer service, and housekeeping services as well as the price of the service provision. For the most part, defined value drivers are in line with business-to-business service management literature, and this supports the argument that security guarding should or at least can be regarded as a professional business-to-business service. 
The findings of the study also show that in order to form a comprehensive picture of security guarding, all the duties of the security guards, i.e., crime prevention, reacting to emergencies, customer service, etc., have to be taken into consideration. For this purpose, customer value has proved to be a promising concept, while highlighting the actual benefits and sacrifices perceived by the customer. Despite its advantages of highlighting the customer's views on security guarding, the approach used also has some limitations. The provision of private security services, especially the rapid growth of the industry, has societal consequences that cannot be understood by only examining the private benefits and sacrifices. The study showed that private security services are of particular value to customers of these services, however, and it can therefore be argued that the private value of security services should be part of the wider societal debate on the role of the private security industry.

\section{Acknowledgement}

The author would like to thank his colleague Mervi Murtonen for her valuable comments and support throughout the research process.

\section{References}

[1] De Waard, J., The private security industry in international perspective. European Journal on Criminal Policy and Research, 7(2), pp. 143-174, 1999.

[2] Van Steden, R. \& Sarre, R., The growth of private security: Trends in the European Union. Security Journal, 20(4), pp. 222-235, 2007.

[3] Zedner, L., Too much security? International Journal of the Sociology of Law, 31(3), pp. 155-184, 2003.

[4] Prenzler, T. \& Sarre, R., Developing a risk profile and model regulatory system for the security industry. Security Journal, 21(4), pp. 264-277, 2008.

[5] Van Steden, R. \& Sarre, R., The tragic quality of contract guards: a discussion of the reach and theory of private security in the world today. The Journal of Criminal Justice Research, 1(1), pp. 1-19, 2010.

[6] Johnston, L., The Rebirth of Private Policing, Routledge: London, pp. 220 221, 1992.

[7] Zeithaml, V., Consumer perception of price, quality, and value: a meansend model and synthesis of evidence. Journal of Marketing, 52(3), pp. 2 22, 1988.

[8] Lindgreen, A. \& Wynstra, F., Value in business markets: What do we know? Where are we going? Industrial Marketing Management, 34(7), pp. 734-748, 2005.

[9] Brooks, D., What is security: Definition through knowledge categorization. Security Journal, 23(3), pp. 225-239, 2009.

[10] Zedner, L., The concept of security: an agenda for comparative analysis. Legal studies, 23(1), 153-175, 2003. 
[11] Sarre, R. \& Prenzler, T., The law of private security in Australia, Thomson LBC: Pyrmont, New South Wales, p. 4, 2009.

[12] Welsh, B., Mudge, M. \& Farrington, D., Reconceptualizing public area surveillance and crime prevention: Security guards, place managers and defensible space. Security Journal, 23(4), pp. 299-319, 2010.

[13] Wakefield, A., Selling Security. The private policing of public space, Willan: Cullompton, 2003.

[14] Button, M., Security Officers and Policing, Ashgate Publishing: Aldershot, 2007.

[15] Manzo, J., How private security officers perceive themselves relative to police. Security Journal, 23(3), 192-205, 2010.

[16] Woodall, T., Conceptualising 'value for the customer': an attributional, structural and dispositional analysis. Academy of Marketing Science Review, 12, pp. 1-42, 2003.

[17] Ulaga, W. \& Chacour, S., Measuring customer-perceived value in business markets. A prerequisite for marketing strategy development and implementation. Industrial Marketing Management, 30(6), pp. 525-540, 2001.

[18] Ravald, A. \& Grönroos, C., The value concept and relationship marketing. European Journal of Marketing, 30(2), pp. 19-30, 1996.

[19] Woodruff, R., Customer value: the next source for competitive advantage. Journal of Academy of Marketing Science, 25(2), pp. 139-153, 1997.

[20] Grönroos, C., Service logic revisited: who creates value? And who cocreates? European Business Review, 20(4), pp. 298-314, 2008.

[21] Payne, A. \& Holt, S., A review of the 'value' literature and implications for relationship marketing. Australasian Marketing Journal, 7(1), pp. 41-51, 1999.

[22] Grönroos, C., Service Management and Marketing. Customer Management in Service Competition ( $3^{\text {rd }}$ edition), John Wiley \& Sons: Haddington, 2007.

[23] Morgan, G. \& Smircich, L., The case for qualitative research. The Academy of Management Review, 5(4), pp. 491-500.

[24] Easterby-Smith, M. \& Thorpe, R., Management Research. An Introduction ( $2^{\text {nd }}$ edition), Sage: London, 2002.

[25] Denzin, N., The Research Act in Sociology. Butterworth: London, 1970.

[26] Holstein, J. \& Gubrium, J., Active Interviewing (Chapter 8). Qualitative Research: Theory, Method and Practice, ed. Silverman, D., Sage: London, p. 113-129, 1997.

[27] Flanagan, J., The critical incident technique. Psychological Bulletin, 51(4), pp. 327-358, 1954.

[28] Barry, J. \& Terry, T., Empirical study of relationship value in industrial services. Journal of Business \& Industrial Marketing, 23(4), pp. 228-241, 2008. 